\title{
P02.98. Effect of selected plant extracts on haemozoin concentration in malaria patients
}

\author{
U Dibua*, A Kalu \\ From International Research Congress on Integrative Medicine and Health 2012 \\ Portland, Oregon, USA. 15-18 May 2012
}

\section{Purpose}

To extract haemozoin from the blood sample containing malaria parasites and to screen for and compare both conventional antimalarial drugs and selected plant extracts.

\section{Methods}

Haemozoin was extracted from blood samples of all the malaria positive patients studied by centrifugation, and the concentration was analyzed spectrophotometrically at $400 \mathrm{~nm}$ wavelength. Comparative anti-malaria activity of some conventional antimalarials, including Maldox, Halfan, Artecxin, Amatem, Mefloquine (quinolines) and Malmed, as well as the leaf and stem back extracts of some local plants (Sarcocephalius latifolius and Alstonia boonei), was evaluated to establish the most effective agent for malaria therapy. Each was administered to patients in each malaria episode, and the absorbance of haemozoin produced determined at $400 \mathrm{~nm}$ wavelength. Packed cell volume (PCV) was estimated to establish the proportion of red blood cells before and after haemozoin production, using a microhaematocrit reader.

\section{Results}

All the chemical antimalarial drugs used effected reduction in haemozoin concentration. However, Mefloquine (quinolines) showed the highest activity with a significant difference of $\mathrm{p}=0.01$. The plant extracts similarly exerted significant reduction in the hemozoin concentration. However, Alstonia boonei extract was the most effective in haemozoin reduction $(\mathrm{p}<0.01)$. Of all the therapeutants (chemical and plant extracts) tested, Alstonia boonei stem back extract most significantly reduced haemozoin production $(\mathrm{p}<0.01)$.

University of Nigeria, Nsukka, Enugu, Nigeria

\section{Conclusion}

The potential use of Alstonia boonei stem back extract as an effective antimalarial is evident from the study in consonance with its use in folkloric medicine.

Published: 12 June 2012

doi:10.1186/1472-6882-12-S1-P154

Cite this article as: Dibua and Kalu: P02.98. Effect of selected plant extracts on haemozoin concentration in malaria patients. BMC Complementary and Alternative Medicine 2012 12(Suppl 1):P154.
Submit your next manuscript to BioMed Central and take full advantage of:

- Convenient online submission

- Thorough peer review

- No space constraints or color figure charges

- Immediate publication on acceptance

- Inclusion in PubMed, CAS, Scopus and Google Scholar

- Research which is freely available for redistribution

Submit your manuscript at www.biomedcentral.com/submit
( Biomed Central
() 2012 Dibua and Kalu; licensee BioMed Central Ltd. This is an Open Access article distributed under the terms of the Creative Commons Attribution License (http://creativecommons.org/licenses/by/2.0), which permits unrestricted use, distribution, and reproduction in any medium, provided the original work is properly cited. 